\title{
Multiculturalism and Early Modern Drama
}

\author{
Scott Oldenburg
}

In the twilight hours of May 5, 1593, a handbill was anonymously posted to the door of Austin Friars, the Dutch Church of London. Written in what might be generously described as an erratic pentameter, the bill, known as the Dutch Church Libel, alleged that immigrants, especially those from the Low Countries and France, "eate us up as bread" while "Our pore artificers doe starve \& dye." The libel accuses aliens or strangers (the early modern terms for foreigners) of merely posing as Protestants to enter the realm, artificially raising the prices of goods, putting English craftsmen out of work, spying for foreign governments, and causing rents to increase. The libel failed to bring about the bloody riot it called for, but it did result in several arrests, most notably those of dramatists Thomas Kyd and Christopher Marlowe, for, although the bill was poorly written, it was signed with the unlikely foreign pseudonym of "Tamberlaine," Marlowe's larger-than-life conqueror. ${ }^{1}$

England had been host to a small number of immigrants from the Continent throughout the 1300 and 1400s, but the Reformation led to new levels of immigration (Bolton 1998; Colson 2010; Kim 2001). Even before the major conflicts on the Continent caused thousands to seek refuge in England, Edward VI had granted a charter to establish a stranger church in London. The charter ensured that Protestants from the abroad could "freely and quietly to practise, enjoy, use and exercise their own rites and ceremonies and their own peculiar ecclesiastical discipline, notwithstanding that they do not conform with the rites and ceremonies used in our Kingdom" (Lindeboom 1950, 202). No doubt Edward and his advisors thought that an influx of continental Protestants might facilitate further reform in England, and the charter is remarkable in its formal tolerance for ecclesiastical diversity.

Mary I overturned Edward's accommodations and instead sought the expulsion of Protestant refugees, but many stayed in England despite Mary's orders. At the start of Elizabeth I's reign, immigrants made up roughly 12.5 percent of London's population. Elizabeth placed the stranger churches under the control of the Bishop of London rather than reinstate her brother's more

A New Companion to Renaissance Drama, First Edition. Edited by Arthur F. Kinney and Thomas Warren Hopper. (C) 2017 John Wiley \& Sons Ltd. Published 2017 by John Wiley \& Sons Ltd. 
liberal charter. ${ }^{2}$ Still, the stranger churches retained much of their independence and were seen by some to have a positive effect on England's Reformation. ${ }^{3}$ The anonymous play New Custom (1573) highlights the influence of immigrants on English Protestantism: at one point the characters Ignorance and Perverse Doctrine attack an English minister and are vanquished by Light of the Gospell, a Protestant reformer who immigrated to England from the Continent (New Custom 1573, 3.1, D1v). Immigrants to England in turn recognized the debt they owed to Elizabeth. When the Queen visited Norwich, where the stranger population sometimes reached as high as 30 percent, she was treated to lavish pageants, which included a Dutch minister's homage to Elizabeth for protecting refugees and acting as "the nourse of Christ his church" (Galloway1984, 256, 264).

Early modern attitudes about the religious conviction of immigrants were not always or uniformly positive, however. The Dutch Church Libel alleged that some immigrants only claimed to be Protestant refugees to gain entry to the realm. Immigrants were also sometimes suspected of bringing to England objectionable forms of Protestantism. For example, in 1575 two Dutch immigrants in London were executed for obstinately holding to their Anabaptist beliefs. ${ }^{4}$ Performed several decades later, John Marston's The Dutch Courtesan continued the association of immigrants with subversive religions that might contaminate English faith. In that play the Dutch courtesan with the oddly Italianate name of Franceschina is a member of the Family of Love, as are several English characters apparently in need of reform. Paranoia about the influence and impact of immigration on the realm was inconsistent, however, typically to tensions abroad, dearth, or perceived increases in immigration.

Concerns about how many immigrants had entered the realm led the state to institute the Returns of Aliens, a periodic census of all aliens or strangers in London. Among the many French and Dutch names listed in the Returns one may also find Flemish, Walloon, Italian, Spanish, Scottish, and Irish names, as well as entries like "Gregory Negro, merchaunt, estr" or "Ferdinando, a blackamore." ${ }^{5}$ As C. J. Sisson (1938) has shown, although associated with the Italian Reformed Church and the English Church respectively, names like "Barnard Lewes, marchante" and "Ferdinando Alvores" turn out to be "marranos" or converted Jews hailing from Portugal. ${ }^{6}$ The sizes of the African and Jewish communities in England were significantly smaller than those of the French, Dutch, Flemish, Italian, and Scottish, but still suggest that even as plays like Shakespeare's Othello and Marlowe's The Jew of Malta indulged audiences in a kind of distant exoticism, they also gestured to diversity closer to home. ${ }^{7}$

England was thus confronted with issues of multiculturalism throughout the sixteenth and seventeenth centuries. That multiculturalism was a good deal different from its present-day counterpart, however. Early modern multiculturalism might focus on differences of complexion, but it also emphasized cultural and linguistic difference in addition to the geohumoral differences discussed by Mary Floyd-Wilson (2003; see also Chapter 33 in this volume). More importantly, early modern subjects were not generally aiming at equality so much as reciprocity and placement within the social hierarchy. Nonetheless, with high numbers of refugees fleeing the Wars of Religion on the Continent, English people seem to have confronted some of the questions addressed by contemporary multiculturalism. What sorts of cultural and economic accommodations should be made for those born outside of the realm? How much assimilation should be expected of immigrants? How open should England's immigration policy be? What kind of cultural impact might immigration have on Englishness? As immigrants had children and married English women and men, what did it mean to be English? These questions were debated in Parliament, among artisans, in legal cases, and, perhaps most publicly, on the stage. 
As the Dutch Church Libel indicates, these issues were not easy to resolve, nor was diversity uniformly accepted. In 1517, well before the major waves of immigration in the latter half of the sixteenth century, thousands of Londoners rioted against strangers in what is known as the Ill or Evil May Day Riot (Holmes 1965). Primarily focused on the privileges of merchant strangers and foreign courtiers, the riot lingered in the collective memory, often cited as a cautionary tale of civil disobedience, and remembered on the stage in the collectively written play Sir Thomas More. As an indication of the state's concerns about the issue, Master of Revels Edmund Tilney evidently insisted that performance of Sir Thomas More "Leave out the insurrection wholly and the cause thereof' (Metz 1989, 32-5).

This is not to say that England was uniformly xenophobic, especially once a sense of shared religion was established among Protestants. Although small-scale anti-alien activity persisted intermittently throughout the sixteenth century, people seem to have taken a certain pride in England's status as a place of refuge for Protestants suffering abroad. At Court, Thomas Dekker's Old Fortunatus (1599) began with a prologue praising Queen Elizabeth: "Her sacred hand hath evermore been knowne,/As soone helde out to straungers as to her owne" (57-9). ${ }^{8}$ John Strype explains that the "better sort of the Queen's subjects were very kind unto these poor Protestants" (1824, 241), a sentiment verified by one Dutch immigrant to Norwich who wrote to his family abroad, "You would never believe how friendly the [Dutch] people are together, and the English are the same and quite loving to our nation" (Tawney and Power 1963, 199). Meanwhile George Abbott, who would go on to become Archbishop of Canterbury, admonished those who were antagonistic to the refugees to recall

the precise Charge which God gave to the Israelites, To deal wel with al Straungers; because the Time once was, when themselves were Strangers in that cruel Land of Aegypt: And not forgetting, that other Nations to their immortal Praise, were a Refuge to the English in their last bloody Persecution in Q. Mary's Days. (Strype 1824, 170)

Indeed, the evocation of Scripture and memory of English Protestant exile under Catholic rule formed key elements in arguing against any xenophobic tendencies.

As Abbott's citation of Scripture suggests, positive attitudes about immigration in part hinged on the premium placed on ideals of hospitality, the bond among coreligionists, and the possibility that regime change could render anyone a stranger. Indeed, memories of exile under Mary were frequently evoked as explanation for encouraging an ethic of hospitality. At the same time, although many would cite a long history of the virtue of hospitality throughout the Bible and extending back to Plato and Aristotle, Felicity Heal $(1990,10)$ has shown that many English writers saw hospitality as a particularly English trait. Thus, if not the practice, at least praise of hospitality was ubiquitous in sermons, political tracts, and in the feasts depicted or alluded to at the end of most comedies (Palmer 1992).

Even so, there were limits to hospitality. The fullest contemporary account of theories of hospitality appears in Christian Hospitalitie Handled Common-place-wise (1632) by Caleb Dalechamp, a French Protestant refugee to England. Dalechamp asserts that although hospitality ought to be extended "to all strangers, Specially strangers professing the true Religion," it also involved responsibilities on the part of immigrants, that "this toleration of strangers is ever to be understood with a double caution: That they be peaceable men and that the land be large enough for them" $(24,11)$. That is, for Dalechamp and many of his contemporaries, hospitality required a reciprocal relationship between English and immigrant. While much of the Dutch Church 
Libel smacks of a hyperbolic xenophobia, concerns about the effect of immigration on the economy were not entirely unfounded. The central issue was the coveted freedom of the city. To open their own shops and retail goods, Londoners had to either inherit the right to do so from their fathers or go through an apprenticeship and pay the entry fee associated with their particular guild (Rappaport 1989, 291-4). Immigrants by definition could not inherit the right, and it was deemed unreasonable to expect skilled adult refugees to enter into extended apprenticeships for nothing more than room and board. Elizabeth, and James after her, thus countenanced the rights of immigrants to peacefully practice their trades in England. This exception to labor practices in London raised important questions for the guilds, which authorized the freedom of the city and regulated the quality of goods and number of apprentices and journeymen any shop could maintain. Many immigrants either were ignorant of the guild statutes or imagined that since the state had authorized their freedom to work that they could operate outside of guild authority (Luu 2005).

This issue was wrestled with throughout the sixteenth and early seventeenth centuries in England. A few months prior to the posting of the Dutch Church Libel, for instance, a bill was introduced to the House of Commons designed to limit the ability of immigrants to retail foreign goods in London. Those in favor of the bill pointed out that not only did most English natives have to go through an arduous apprenticeship to gain the privilege of retailing goods in the city, but that aliens' connections abroad gave them an unfair advantage in the marketplace, resulting in greater poverty among the English. Those against the bill countered that aliens needed to have a way of maintaining themselves, that aliens were being scapegoated, and that "the Riches and Renown of the City cometh by entertaining of Strangers, and giving liberty unto them." The bill was successfully defeated, but the debate itself reveals the diverse attitudes among the English as they found themselves in an increasingly multicultural England (D'Ewes $1693,505-9)$.

While supporters of the bill might appear biased against immigrants, some of their arguments reveal quite a different attitude altogether. Nicholas Fuller, for example, railed,

It is no Charity to have this pity on them to our own utter undoing; for them there ought none to be sworn a Denizen, but he should first swear he is not worth five pound. This is to be noted in these Strangers, they will not converse with us, they will not marry with us, they will not buy any thing of our Country-men. (D’Ewes 1693, 506)

Fuller's anger is clear, yet its source is not properly xenophobia but rather a frustrated desire for greater integration with strangers. Similarly, the debate reveals that many were especially astute about scapegoating. In response to Fuller, Sir Edward Dymock remarked that the bill appeared to have been introduced by Englishmen keen to divert attention away from their own manipulation of markets. Less measured positions were also voiced, however. Sir Walter Ralegh speaking specifically of the Dutch, alleged, "The nature of the Dutchman is to fly to no man but for his profit, and they will obey no man long, now under Spain, now under Mountfort, now under the Prince of Orange, but under no Governour long," and further questioned the religious convictions of Protestant refugees (D'Ewes 1693, 508-9).

Related to the debate over retailing, England had to confront the status of the children of strangers. As Jacob Selwood (2010, 87-128) explains, throughout the seventeenth century courts heard numerous cases brought by the English-born children of immigrants who complained that they should be accorded the rights and privileges of English subjects. Despite a 
1608 ruling that those born in the monarch's territories were by definition the king's subjects, local authorities continued policies ensuring that the children of immigrants were treated as immigrants. That is, they often had to pay higher tax rates and had more difficulty in gaining economic freedom in the city. The children of immigrants thus posed a challenge to ideas of national belonging and how to define Englishness.

The question of the Englishness of children of immigrants was in part taken up by William Haughton in his play Englishmen for My Money (1616). The main plot of the play features three impoverished English gentlemen attempting to woo the three daughters of their Portuguese (and apparently Jewish) creditor. Although the three daughters speak perfect English and were born of an English mother, when a misunderstanding occurs, one of the suitors hurls the epithet "mongrel" at one of the daughters (Campos 2002, 55), emphasizing that from his perspective, the father's cultural influence takes precedence over her birthplace. As Emma Smith (2001) sees it, the three daughters are symbols of the English nation and, paradoxically, the cosmopolitanism of its urban centers.

Although the guilds were intent on limiting the ability of immigrant artisans to outdo their English counterparts, one of the more productive approaches to the problem involved concerted efforts to include immigrants in the guild as "foreign brethren." (Littleton 1995, 180; Kirk and Kirk 1902, 305-14; Scouloudi 1985, 40-4). Guilds thus maintained the scope of their authority, while strangers gained greater integration in the local economy. Although dismissed by David Scott Kastan as "a fantasy of social cohesion" (1991, 153), Thomas Dekker's The Shoemaker's Holiday reflects the integration of immigrant artisans into the guild system. In that play, Simon Eyre's journeyman shoemakers threaten a work stoppage if he fails to hire Hans, the Dutch shoemaker. The Dutch shoemaker turns out to be an English gentleman in apparently convincing disguise, but at this point, in the shoemakers' view, they are standing up for inclusion of strangers in their shop.

Dekker may be a special case, however. He was more than likely the descendant of Dutch immigrants, and this background shows in his texts, which often advocate for English intervention in the Low Countries and tolerance of strangers at home (Jones-Davies 1958, 1: 29-30; Gasper 1990, 20, 37). Rival dramatist John Marston was the son of an Italian immigrant to England, and while one can find traces of Italian commedia dell'arte in Marston's plays, he does not seem to have advocated on behalf of immigrant communities the way Dekker did, and may well have satirized Dekker's The Honest Whore in his play The Dutch Courtesan (Scott 2000, 212).

The theater was perhaps an especially charged space to address issues of England's increasingly multicultural character. Immigrants lived throughout London, but especially in the Liberties, where guild ordinances were likely to carry less force. These neighborhoods also happened to be near the theaters so that just before possibly seeing representations of immigrants on the stage, playgoers likely heard and saw Dutch, French, and Flemish families on the streets (Scouloudi $1985,77)$. In addition to dramatists with immigrant heritages, actors also represented some of the diversity of England. The Lord Chamberlain's Men had at least one actor fluent in Welsh, and as the King's Men they added to their cast Nicholas Tooley, whose mother was Flemish. William Shakespeare lodged with a French Huguenot family; Christopher Marlowe's father had been apprenticed to a Dutch shoemaker (Nicholl 2007; Kuriyama 2002, 10, 12).

Despite such connections, there is no denying that the stage, especially the early Elizabethan stage, provided a platform for xenophobic sentiments. Although printed in 1595, the anonymous play The Pedlers Prophecie was likely performed in the 1560 s and deals in part with the anxieties around the recent rise in immigration from the Continent. For example, an artisan registers the popular complaint about immigrants: 
But Aliaunts chop up houses so in the Citie, That the poore craftsmen must needs depart. And beg if they will, the more is the pittie.

$(1595, \mathrm{D} 2)$

The titular peddler then goads the artisan, explaining that if he were a landlord he too would rent only to aliens because they pay more. Taunting a nearby mariner, the peddler rails,

Three parts in London are alreadie Alians,

Other mongrels, Alians children, mischieuously mixed,

And that with the most detestable Barbarians,

Which here for ever hath their dwellings fixed:

Still you Mariners bring them in daily,

So you may haue pence,

You make your selues rich and go gaily,

I would you were as readie to carry them hence.

$(\mathrm{D} 2 \mathrm{v})$

If immigration is a problem, the peddler further blames those that bring immigrants to England for a profit. The Pedlers Prophecie ends with a trial that asks for a rethinking of the anti-alien complaints registered in the play. Here the Judge and an Interpreter surmise that many of the problems of the play can be attributed not to mariners or immigrants but to "base medlers" like the peddler himself $(\mathrm{F} 3-\mathrm{F} 3 \mathrm{v})$. Elizabethan and Jacobean plays might blame immigrants for socioeconomic problems in England, but like The Pedlers Prophecie, they also typically find antialien sentiment to be a symptom of deeper problems in the commonwealth.

Even in The Shoemaker's Holiday, however, Dutch speech is the object of considerable ridicule. Indeed, the garbled stage dialects of immigrant characters were a common source of humor in the period. The practice was so common that in An Apology for Poetry, Sir Philip Sidney complained about plays that tended "to jest at strangers because they speak not English so well as we do" ([1595] 1970, 79-80). In the wide-ranging and essential Images of Englishmen and Foreigners, A. J. Hoenselaars (1992) sees stage dialect and other features of immigrant stereotypes as a measure of English patriotism, but more recent criticism has sought to nuance this argument. Lloyd Edward Kermode examines stage representations of aliens but finds "Elizabethans' reflections on English identity as increasingly a process of finding and absorbing alien aspects around them and less the simple phenomenon of frictionally and uncooperatively rubbing up 'against nonEnglishness"' (2009, 9). For Kermode, a play like Englishmen for My Money with its marriage of Englishmen to half-alien women exemplifies this process of incorporation which seeks "to hybridize and strengthen Englishness" (6-7). It should be noted that the will to incorporate immigrants into English life occurred outside of the theater as well, in civic pageantry, guilds, and in actual marriages. Along similar lines, looking specifically at foreign languages presented on the English stage, Marianne Montgomery notes that the French and Welsh languages register as alien but also as the roots of English so that stage dialects often "emphasize not a self-other dichotomy but rather a productive continuity between self and other" $(2012,19)$.

Marjorie Rubright furthers this complication of a self-other dynamic at work in Angloimmigrant relations. Focusing on the Dutch in England and abroad, Rubright suggests that there was often a subtle resemblance or double vision associated with the Dutch. For Rubright the intelligibility of the stage Dutch in plays like The Shoemaker's Holiday "dramatized the 
propinquity of English and Dutch," while the fact that the London Royal Exchange was modeled after Antwerp's Nieuwe Beurs created an uncanny Dutchness in London's economic center (2014, 89-109, 166-7). That is, rather than othering the Dutch, Rubright finds that "Representations of Anglo-Dutch relations often rattled those notions of Englishness that existed eccentric to concepts of national self-definition" (32).

To take Rubright's work in a slightly different direction, one might consider identifications between English and immigrant that supersede or at least diminish the preeminence of national or ethnic difference. Dekker's The Shoemaker's Holiday again provides an ample case study. Whereas critics like Andrew Fleck (2006) and Kermode (2009, 133-44) have seen the play as expelling or containing the alien in service of national identity, the play can also be seen to be denying the importance of that very identity. While the Dutch skipper and the Englishman disguised as a Dutch shoemaker ultimately serve Simon Eyre's ends, when the English shoemaker Firk is questioned by the mayor and Lincoln about the whereabouts of Hans (Firk doesn't know that Hans is really English), Firk refuses to sell out his Dutch coworker, declaring, "Shall I cry treason to my corporation? No." (4.4.97-8). Firk prioritizes his shared identity as a shoemaker over his identity as English even when turning Hans in would involve personal gain. Such things happened offstage as well. In 1554, when Mary I was attempting to expel all strangers, two Dutch shoemakers were arrested for loitering and faced expulsion until members of the Cordwainers' Company intervened on their behalf (Pettegree 1986, 123). While shoemakers may seem like an especially tolerant group, similar stories can be found about dyers, weavers, merchants, and others.

Since Dekker appears to have had a unique connection to the Dutch, his play might be deemed an exception. Thomas Middleton's depiction of strangers is similarly sympathetic. Middleton does not accord immigrants the central role that Dekker often does but he also resists vilifying immigrants. In No Wit/Help Like a Woman's (1611), for example, a Dutch merchant thwarts the machinations of the vice Savorwit and, as Marianne Montgomery suggests, "temporarily offers a point of identification for the audience" $(2012,67)$. The merchant, explains Montgomery, is a guarantor of truth in this play.

The stage, then, offered a space for thinking through the challenges of immigration and multiculturalism. Early Elizabethan plays might allow a platform for the more reactionary attitudes arising from the unprecedented influx of immigrants in the 1560s and 1570s, but in the 1590s plays like The Shoemaker's Holiday sought to question such sentiments. By the seventeenth century, immigration would continue to receive more nuance on the stage. For instance, in Dekker's 1620 play The Noble Spanish Soldier, when the protagonist Balthazar faces exile, he declares,

If I were [exiled], I lose nothing, I can make any Country mine: I have a private Coat for Italian Steeletto's, I can be treacherous with the Wallowne, drunke with the Dutch, a Chimney-sweeper with the Irish, a Gentleman with the Welsh, and turne arrant theefe with the English, what then is my Country to me?" (3.3.100-4)

Here Balthazar heaps stereotype upon stereotype, but ends with a particularly unflattering stereotype of the English. Since most English playgoers would likely not identify themselves as thieves, the passage effectively undermines the other familiar stereotypes, rendering all stereotypes laughable.

Of course, stereotypes endure despite the cultural work of the early modern stage and various attempts to forge ties with immigrants throughout the period. It may be that the rise of national 
identity as a dominant mode of identification amplifies the potential for anti-immigrant sentiment. Xenophobia reached a frenzied pitch in the long eighteenth century, the period that also saw the rise of national consciousness and the British Empire (Statt 1995). During the sixteenth and seventeenth centuries, the nation was only emergent, visible in the historical record but in competition with dynastic definitions of borders and identities. It may be that the lack of a pervasive national consciousness lent itself to early modern subjects' ability to imagine and to some extent practice inclusive communities founded on shared religion or craft. It is precisely these early multicultural communities that the rhetoric of the Dutch Church Libel sought to disrupt. Sadly, much of the bile of the Dutch Church Libel sounds uncannily like anti-immigrant sentiments of today. As we deepen our understanding of immigration and diversity in the early modern period, we should also keep in mind how such studies might complicate the idea of national identity then now.

\section{Notes}

1 For the full text of the Dutch Church Libel and discussion of its connection to Marlowe, see Freeman (1973); see also Kermode (2009, 71-3).

2 On the demographics of immigrants in early modern England, see William Cunningham (โ1897] 1969, 144-6); Pettegree (1986, 21); Scouloudi (1989).

3 There are numerous works on the history of the stranger churches in England. A good starting point is Pettegree (1986).

4 This episode is discussed in several histories of the English Reformation, as John Foxe argued for tolerance of the dissenters. See Grell (2002); Elton (1984).

5 Kirk and Kirk (1902, 220, 235). The Huguenot Society of London has transcribed all the Returns and other similar documents and made them available in CD-ROM format. On the African community in early modern England, see Habib (2008) and Onyeka (2015).

6 Kirk and Kirk (1902, 279). On Jews in early modern England, see Prior (1988-90); Selwood (2010); Shapiro (1996); and Wolf (1929).

7 One recent collection, Espinosa and Ruiter (2014), examines several of Shakespeare's plays from this perspective.

8 Unless otherwise indicated, references to Dekker's plays are from Bowers (1953).

\section{REFERENCES AND Further READING}

Adelman, Janet. 2008. Blood Relations: Christian and Jew in Merchant of Venice. Chicago: University of Chicago Press.

Backhouse, Marcel. 1995. The Flemish and Walloon Communities at Sandwich during the Reign of Elizabeth I, 1561-1603. Brussels: Koninklijke Academie voor Wetenschappen, Letteren en Schone Kunsten.

Billing, Christian M. 2008. "The Dutch Diaspora in English Comedy: 159 to 1618." In Transnational Exchange in Early Modern Theater, edited by Robert Henke and Eric Nichols, 119-40. Farnham: Ashgate.
Bolton, James L. 1998. The Alien Communities of London in the Fifteenth Century: The Subsidy Rolls of 1440 and 1483-4. Stamford: Brepols.

Bowers, Fredson, ed. 1953. The Dramatic Works of Thomas Dekker. 4 vols. Cambridge: Cambridge University Press.

Campos, Edmund Valentine. 2002. “Jews, Spaniards, and Portingales: Ambiguous Identities of Portuguese Marranos in Elizabethan England." English Literary History 69: 599-616.

Colson, Justin. 2010. "Alien Communities and Alien Fraternities in Later Medieval London." London Journal 35: 111-43. 
Cottret, Bernard. 1991. The Huguenots in England, Immigration and Settlement c.1550-1700. Cambridge: Cambridge University Press.

Cunningham, William. (1897) 1969. Alien Immigrants to England. London: Frank Cass.

Dalechamp, Caleb. 1632. Christian Hospitalitie Handled Common-place-wise. Cambridge: Thomas Buck.

D'Ewes, Simonds. 1693. A Compleat Journal of the Votes, Speeches, and Debates, Both of the House of Lords and House of Commons Throughout the Whole Reign of Queen Elizabeth. London.

Elton, G. R. 1984. "Persecution and Toleration in the English Reformation." In Persecution and Toleration: Papers read at the Twenty-Second Summer Meeting and the Twenty-Third Meeting of the Ecclesiastical History Society, edited by William J. Sheils, 163-87. Oxford: Blackwell.

Espinosa, Ruben, and David Ruiter. 2014. Shakespeare and Immigration. Farnham: Ashgate.

Esser, Raingard. 1992. "Social Concern and Calvinistic Duty: The Norwich Strangers' Community." In Het Beloofde Land, Acht Opstellen Over Werken, Geloven en Vluchten Tijdens de XVIe en XVIIe Eeuw, Bijdragen tot de geschiedenis van de Westhoek, edited by Jaak Decaestecker, 172-84. Dikkebus: Westhoek.

Fleck, Andrew. 2006. "Marking Difference and National Identity in Dekker's The Shoemaker's Holiday." Studies in English Literature 1500-1900 46: 349-70.

Floyd-Wilson, Mary. 2003. English Ethnicity and Race in Early Modern Drama. Cambridge: Cambridge University Press.

Freeman, Arthur. 1973. "Marlowe, Kyd, and the Dutch Church Libel." English Literary Renaissance 3: 44-52.

Galloway, David. 1984. Norwich: 1540-1642. Records of Early English Drama. Toronto: University of Toronto Press.

Gasper, Julia. 1990. The Dragon and the Dove: The Plays of Thomas Dekker. Oxford: Oxford University Press.

Goose, Nigel, and Lien Bich Luu, eds. 2005. Immigrants in Tudor and Stuart London. Brighton: Sussex Academic Press.

Grell, Ole Peter. 1996. Calvinist Exiles in Tudor and Stuart England. Farnham: Ashgate.

Grell, Ole Peter. 2002. "Exile and Tolerance.” In Tolerance and Intolerance in the European Reformation, edited by Ole Peter Grell and Bob Scribner, 164-81. Cambridge: Cambridge University Press.
Gwynn, Robin D. 1985. Huguenot Heritage: The History and Contribution of the Huguenots in Britain. London: Routledge.

Habib, Imtiaz. 2008. Black Lives in the English Archives, 1500-1677. Farnham: Ashgate.

Haughton, William. (1616) 2009. Englishmen for My Money. In Three Renaissance Usury Plays, edited by Lloyd Edward Kermode, 164-174. Manchester: Manchester University Press.

Haynes, Alan. 1977. "Italian Immigrants in England, 1558-1603." History Today 27: 485-534.

Heal, Felicity. 1990. Hospitality in Early Modern England. Oxford: Clarendon Press.

Hessels, Joannes Henricus. 1887-97. Ecclesiae LondinoBatavae Archivum. 3 vols. Cambridge.

Hoenselaars, A. J. 1992. Images of Englishmen and Foreigners in the Drama of Shakespeare and His Contemporaries. Rutherford, NJ: Farleigh Dickinson University Press.

Holmes, Martin. 1965. "Evil May-Day, 1517: The Story of a Riot." History Today 15: 642-50.

Jones-Davies, Marie-Therese. 1958. Un peintre de la vie londonienne: Thomas Dekker. 2 vols. Paris: Collection des Études Anglaises.

Kastan, David Scott. 1991. "Workshop and/as Playhouse." In Staging the Renaissance: Reinterpretations of Elizabethan and Jacobean Drama, edited by David Scott Kastan and Peter Stallybrass, 151-63. New York: Routledge.

Kermode, Lloyd Edward. 2009. Aliens and Englishness in Elizabethan Drama. Cambridge: Cambridge University Press.

Kim, Keechang. 2001. Aliens in Medieval Law: The Origins of Modern Citizenship. Cambridge: Cambridge University Press.

Kirk, R. E. G., and Ernest Kirk, eds. 1902. Returns of Aliens Dwelling in the City and Suburbs of London, 1525-1571. Vol. 2. London: Aberdeen.

Kuriyama, Constance Brown. 2002. Christopher Marlowe: A Renaissance Life. Ithaca: Cornell University Press.

Lindeboom, Johannes. 1950. Austin Friars: History of the Dutch Reformed Church in London, 1550-1950. The Hague: Martinus Nijhoff.

Littleton, Charles Galton. 1995. "Geneva on Threadneedle Street: The French Church of London and Its Congregation, 1560-1625." Dissertation. University of Michigan.

Luu, Lien Bich. 2005. Immigrants and the Industries of London, 1500-1700. Farnham: Ashgate. 
Metz, G. Harold. 1989. “'Voice and credyt': The Scholars and Sir Thomas More." In Shakespeare and Sir Thomas More: Essays on the Play and Its Shakespearian Interest, edited by T. Howard Hill, 11-44. Cambridge: Cambridge University Press.

Montgomery, Marianne. 2012. Europe's Languages on England's Stages, 1590-1620. Farnham: Ashgate.

New Custom. 1573. A New Interlude No Lesse Wittie Than Pleasant, Entitled New Custom. London.

Nicholl, Charles. 2007. The Lodger Shakespeare: His Life on Silver Street. New York: Viking.

Onyeka. 2015. Blackamoores: Africans in Tudor England, Their Presence, Status and Origins. London: Narrative Eye.

Palmer, Daryl W. 1992. Hospitable Performances: Dramatic Genre and Cultural Practices in Early Modern England. West Lafayette, IN: Purdue University Press.

Panayi, Panikos, ed. 2006. Germans in Britain since 1500. Hambledon: Continuum.

The Pedlers Prophecie. 1595. London.

Pettegree, Andrew. 1986. Foreign Protestant Communities in Sixteenth-Century London. Oxford: Clarendon Press.

Prior, Roger. 1988-90. "A Second Jewish Community in Tudor London.” Jewish Historical Studies 31: 137-52.

Rappaport, Stephen. 1989. Worlds Within Words: Structures of life in Sixteenth-Century London. Cambridge: Cambridge University Press.

Rubright, Marjorie. 2014. Doppelgänger Dilemmas: AngloDutch Relations in Early Modern English Literature and Culture. Philadelphia: University of Pennsylvania Press.

Scott, Michael. 2000. "Ill-mannered Marston." In The Drama of John Marston, edited by T. F. Wharton, 212-30. Cambridge: Cambridge University Press.

Scouloudi, Irene. 1985. Returns of Strangers in the Metropolis 1593, 1627, 1635, 1639: A Study of an Active Minority. Huguenot Society of London, Quarto Series, vol. 57. London: Huguenot Society of London.

Scouloudi, Irene. 1989. "Notes on Strangers in the Precinct of St. Katherine-by-the-Tower c.1500-1687, and on the 'Flemish Cemetery."' Proceedings of the Huguenot Society 25: 75-82.
Selwood, Jacob. 2010. Diversity and Difference in Early Modern London. Farnham: Ashgate.

Shapiro, James. 1996. Shakespeare and the Jews. New York: Columbia University Press.

Sidney, Sir Philip. (1595) 1970. An Apology for Poetry. Indianapolis: Bobbs-Merrill.

Sisson, C. J. 1938. "A Colony of Jews in Shakespeare's London." Essays and Studies 23: 37-52.

Smith, Emma. 2001. "'So much English by the mother': Gender, Foreigners, and the Mother Tongue in William Haughton's Englishmen for My Money." Medieval and Renaissance Drama in England 13: 165-81.

Statt, Daniel. 1995. Foreigners and Englishmen: The Controversy over Immigration and Population, 1660-1760. Newark: University of Delaware Press.

Strype, John. 1824. Annals of the Reformation. Vol. 4. Oxford.

Tawney, R. H., and Eileen Power, eds. 1963. Tudor Economic Documents. Vol. 1. London: Longmans.

Vigne, Randolph, and G. Gibbs, eds. 1995. The Strangers' Progress: Integration and Disintegration of the Walloon and Huguenot Refugee Community, 1567-1889. Essays in Memory of Irene Scouloudi. London: Huguenot Society of Great Britain and Ireland.

Vigne, Randolph, and Charles Galton Littleton, eds. 2002. From Strangers to Citizens: The Integration of Immigrant Communities in Britain, Ireland and Colonial America, 1550-1750. London: Huguenot Society of Great Britain and Ireland.

Villani, Stefano. 2010. "The Italian Protestant Church of London in the Seventeenth Century." In Exiles, Emigrés and Intermediaries: Anglo-Italian Cultural Transactions, edited by Barbara Schaff, 217-36. New York: Rodopi.

Wolf, Lucien. 1929. Jews in Elizabethan England. London: Spottiswoode, Ballantyne.

Wyatt, Michael. 2005. The Italian Encounter with Tudor England: A Cultural Politics of Translation. Cambridge: Cambridge University Press.

Yungblut, Laura Hunt. 1996. "Strangers settled here among us": Policies, Perceptions and the Presence of Aliens in Elizabethan England. New York: Routledge. 